Widya Cipta: Jurnal Sekretari dan Manajemen

Volume 3 No. 2 September 2019

P-ISSN 2550-0805 E-ISSN 2550-0791

https://doi.org/10.31294/widyacipta.v3i1

\title{
Pengaruh Kualitas Pelayanan Terhadap Kepuasan Pelanggan (Orang Tua Murid Taam Aisyah Bandung)
}

\author{
Wendy Muliadi ${ }^{1}$, Muhammd Irsday Raspati ${ }^{2}$ \\ ${ }^{1,2}$ STIE Kridatama Bandung \\ 1e-mail: wendymuliadi@gmail.com \\ 2e-mail: musadrapati@gmail.com

\begin{tabular}{ccc}
\hline Diterima & Direvisi & Disetujui \\
$19-07-2019$ & $18-09-2019$ & $23-09-2019$ \\
\hline
\end{tabular}

\begin{abstract}
Abstrak: Tujuan penelitian ini adalah untuk mengetahui kualitas pelayanan, kepuasan pelanggan, dan untuk mengetahui pengaruhnya atas kualitas pelayanan terhadap kepuasan pelanggan pada TAAM Aisyah Bandung, dan untuk mengetahui pengaruh kualitas pelayanan terhadap kepuasan pelanggan pada TAAM Aisyah Bandung. Metode penelitian yang digunakan adalah metode analisis deskriptif dan analisis asosiatif. Sumber data yang digunakan adalah data primer dan data sekunder, yaitu dengan melakukan observasi serta menyebarkan kuesioner kepada responden. Teknik pengambilan sampel dalam penelitian ini adalah lembar angket teknik sensus. Ukuran sampel dalam penelitian ini sebanyak 33 responden. Penelitian ini membuktikan bahwa kualitas pelayanan yang dirasakan pada TAAM Aisyah Bandung dalam kondisi sangat baik dengan tingkat pencapaiannya sebesar 141,84 dan kualitas pelayanan yang diharapkan pada TAAM Aisyah Bandung dalam kondisi sangat baik dengan tingkat pencapaiannya sebesar 145,78 dengan koefisien korelasi Rank Spearman yang di dapat sebesar $\rho=(+) 0,728$ hasilnya positif artinya jika kualitas pelayanan baik maka kepuasan akan meningkat, berdasarkan kriteria Champion hubungan tersebut cukup kuat, kualitas pelayanan hanya mampu berpengaruh sebesar 52,99\% terhadap kepuasan pelanggan pada TAAM Aisyah Bandung.
\end{abstract}

Kata Kunci : Pemasarn, Kualitas Layanan,Kepuasan Pelangan

Abstract: The purpose of this study was to determine the quality of service, customer satisfaction, and to determine the effect of service quality on customer satisfaction at TAAM Aisyah Bandung, and to determine the relationship of service quality to customer satisfaction at TAAM Aisyah Bandung. The research method used is descriptive analysis and associative analysis. Data sources used are primary data and secondary data, namely by observing and sending questionnaires to respondents. The sampling technique in this study was the census questionnaire sheet. The number of samples in the study were 33 respondents. This research proves that the quality of service calculated at TAAM Aisyah Bandung is in very good condition with an assessment level of 141.84 and the expected service quality at TAAM Aisyah Bandung is in very good condition with a return rate of 145.78 with a high rank of Spearman which can be equal to $\rho=(+) 0.728$ positive results mean good service quality, satisfaction will increase, based on Champion criteria the relationship is strong enough, service quality is only able to reach $52.99 \%$ of customer satisfaction at TAAM Aisyah Bandung.

Keywords: Marketing, Service Quality, Customer Satisfaction

\section{PENDAHULUAN}

Lembaga pendidikan yang ingin memenangkan kompetisi dalam era industrialisasi yang semakin kompetitif sekarang ini, selalu berupaya meningkatkan kualitas pelayanannya. Kualitas adalah segala sesuatu yang mampu memenuhi keinginan atau kebutuhan pelanggan (meeting the needs of costumers). Kualitas yang memenuhi standar maka akan bermanfaat dalam menumbuhkan dan meningkatkan minat orang tua murid untuk memiliki atau merasakan jasa tersebut. Taam Aisyah Taman merupakan lembaga pendidikan yang bergerak di bidang jasa pendidikan usia dini. Berdasarkan informasi dan data-data yang di peroleh penulis dari Taam Aisyah mengalami ketidaksetabilan atau penurunan murid Taam Aisyah yang terjadi sejak tahun 2012 hingga 2017 mengalami penurunan. 
Tabel 1 Jumlah Murid dari tahun 2013 s.d 2018

\begin{tabular}{|c|c|c|}
\hline No & Tahun Ajaran & $\begin{array}{c}\text { Jumlah } \\
\text { Murid }\end{array}$ \\
\hline 1 & $2013 / 2014$ & 58 \\
\hline 2 & $2014 / 2015$ & 34 \\
\hline 3 & $2015 / 2016$ & 42 \\
\hline 4 & $2016 / 2017$ & 27 \\
\hline 5 & $2017 / 2018$ & 33 \\
\hline
\end{tabular}

Sumber: data Taam Aisyah Bandung

Di lihat data- data yang ada dari tahun tahun ajaran mengalami penurunan, yang merupakan masalah dalam penelitian ini, dan merupakan fenomena serta penelitian awal penulis serta untuk mendukung kemajuan bertambahnya santri agar tidak terjadi penurunan yaitu dengan memberikan kualitas pelayanan yang baik dan memahami apa yang terjadi di Taam Aisyah. Selain fenomena di atas masih ada fenomena lainnya yaitu banyaknya keluhan dari orang tua murid terhadap pelayanan pada Taam Aisyah, yaitu seperti :

1. Staf administrasi dalam menyikapi informasi kepada orang tua murid kurang cepat.

2. Keterlambatan guru dalam hal mengajar yang tidak sesuai dengan jam yang seharunya masuk pukul 08.00 WIB

3. Lokasi tempat belajar murid yang berada di bawah (Basement) menyebabkan orang tua murid kawatir atas struktur bagunannya.

Sehubungan dengan paparan dan keterangan di atas, dalam meningkatkan kualitas pelayanan maka pelayanan yang diberikan harus dapat memperhatikan kepentinggan para pelanggan, karena penerimaan para pelanggan akan sangat berpegaruh pada kualitas pelayanan tersebut. Baik pada saat proses berlangsung maupun sesudah proses pemberian jasa berlangsung. Perusahaan yang dapat memberikan pelayanan berkulitas secara konsisten sesuai dengan harapan pelanggan, dapat menumbuhkan kepuasan pelanggan. Kualitas yang unggul dapat digunakan sebagai alat untuk meraih keunggulan bersaing dalam berbagai organisasi atau perusahaan agar tercapainya tujuan .

\section{Kerangka Pemikiran}

Taam Aisyah merupakan lembaga pendidikan yang bergerak dibidang jasa pendidikan usia dini. Fenomena yang terjadi berdasarkan informasi dan data-data yang di peroleh penulis dari Taam Aisyah mengalami ketidaksetabilan atau penurunan murid Taam yang terjadi sejak tahun 2013.
Rosenberg dalam Sugianto (2009) menyatakan bahwa

"Manajemen pemasaran adalah perencanaan, pelaksanaan dan pengendalian operasi pemasaran total, termasuk perumusan tujuan pemasaraan, kebijakan pemasaran, program pemasaran dan strategi pemasaran yang ditunjukkan untuk menciptakan pertukaran yang dapat memenuhi tujuan individu maupun organisasi”.

Manajer pemasaran harus memiliki dua tangung jawab dalam suatu perusahaan. Tangung jawab tersebut menurut pendapat Gasper (2005) adalah ; Pertama mereka harus berpartisifikasi dalam perumusan strategi-strategi dan kebijaksanaan yang didesain untuk membantu perusahaan memenangkan persaingan global melalui keunggulan kualitas total; Kedua mereka harus menawarkan kualitas pemasaran, juga kualitas produksi. aktivitas pemasaran seperti : riset pemasar, pelatihan tenaga penjual, periklanan, pelayanan pelanggan dan lainlain harus dilakukan dengan berfokus pada kualitas yang ditetapkan pada standar-standar tinggi. Apabila perusahaan mampu melakukan tangung jawab tersebut di atas, maka perusahaan tersebut akan mampu bersaing secara global untuk memenangkan konpetisi pasar. Jadi, tenaga - tenaga pemasar termasuk manajer pemasaran tidak boleh mengeluh bahwa " kami dari bagian pemasaran tidak mampu menjual produk, karena produk itu berkualitas jelek atau kami tidak mampu mempengaruhi konsumen / pelanggan untuk bergabung dengan perusahaan kita, karena mereka tidak mampu melunasi harga jual produk. Tetapi, dengan pendekatan yang benar serta penjelasan yang masuk diakal, maka tidak mustahil untuk memikat hati para konsumen / pelanggan.

\section{Pemasaran}

Kotler dan Keller (2009), mengutip Asosiasi Pemasaran Amerika yang memberikan definisi berikut, "Pemasaran adalah satu fungsi organisasi dan seperangkat proses untuk menciptakan, mengomunikasikan, dan menyerahkan nilai kepada pelanggan dan mengelola hubungan pelanggan dengan cara yang menguntungkan organisasi dan para pemilik sahamnya. "Menurut Kotler dan Armstrong (2012), "Marketing as the process by which companies create value for customers and build strong customer relationships in order to capture value from customers in return", artinya menyatakan bahwa pemasaran sebagai proses dimana perusahaan menciptakan nilai bagi pelanggan dan membangun hubungan pelanggan yang kuat untuk menangkap nilai dari pelanggan sebagai imbalan. 
Pengertian Manajemen Pemasaran menurut Sofjan Assauri (2013), adalah "Manajemen pemasaran merupakan kegiatan penganalisisan, perencanaan, pelaksanaan, dan pengendalian programprogram yang dibuat untuk membentuk, membangun, dan memelihara keuntungan dari pertukaran melalui sasaran pasar guna mencapai tujuan organisasi (perusahaan) dalam jangka panjang".

Dari beberapa definisi-definisi di atas, maka dapat ditarik kesimpulan bahwa pemasaran adalah proses menciptakan, mengomunikasikan, dan menyerahkan nilai yang bertujuan untuk memahami kebutuhan dan keinginan konsumen akan produk dan jasa, sehingga tercipta hubungan pelanggan yang menghasilkan penjualan.

\section{Definisi Kualitas Pelayanan}

Pelayanan merupakan kegiatan yang dilakukan oleh perusahaan penyedia jasa untuk melayani kebutuhan dan keinginan konsumen agar konsumen dapat terpuaskan.

Pelayanan yang diberikan harus dapat memperhatikan kepentinggan para pelanggan, karena penerimaan para pelanggan akan sangat berpegaruh pada kualitas pelayanan tersebut. Baik pada saat proses berlangsung maupun sesudah proses pemberian jasa berlangsung.

Kualitas adalah suatu kondisi dinamis yang berpengaruh dengan produk, jasa, manusia, proses dan lingkungan yang memenuhi atau melebihi harapan Tjiptono (2001). Maka definisi kualitas pelayanan dapat diartikan sebagai upaya pemenuhan kebutuhan dan keinginan konsumen serta ketepatan penyampaiannya dalam mengimbangi harapan konsumen Tjiptono (2007). Kualitas pelayanan (service quality) dapat diketahui dengan cara membandingkan persepsi para konsumen atas pelayanan yang nyata-nyata mereka terima/peroleh dengan pelayanan yang sesungguhnya mereka harapkan/ inginkan terhadap atribut-atribut pelayanan suatu perusahaan.

Menurut Lovelock dan Wright, (2007) Kualitas pelayanan memegang peran penting dalam hubungannya memengaruhi tingkat kesetiaan konsumen, di mana semakin baik kualitas pelayanan perusahaan yang diberikan semakin tinggi juga kesetiaan konsumen.
Penelitian Kumar, et al. 2009) menunjukkan bahwa kualitas pelayanan yang baik akan meningkatkan kepuasan pelanggan dan kesetiaan pelanggan. Penelitian Prasetyo (2013) juga menunjukkan bahwa kualitas pelayanan berpengaruh secara positif terhadap kesetiaan pelanggan, artinya jika kualitas pelayanan meningkat maka kesetiaan pelanggan juga meningkat.

Menurut pendapat Kotler (2002) definisi pelayanan adalah setiap tindakan atau kegiatan yang dapat ditawarkan oleh suatu pihak kepada pihak lain, yang pada dasarnya tidak berwujud dan tidak mengakibatkan kepemilikan apapun. Dalam kegiatan produksinya dikaitkan atau tidak dikaitkan pada satu produk fisik. Pelayanan adalah perilaku produsen dalam rangka memenuhi kebutuhan dan keinginan konsumen demi tercapainya kepuasan pada konsumen itu sendiri. Kotler menyebutkan bahwa perilaku tersebut dapat terjadi pada saat, sebelum dan sesudah terjadinya transaksi.

Karakteristik yang berbeda antara layanan jasa dengan produk barang memberikan implikasi yang berbeda dalam upaya untuk memenuhi kebutuhan konsumen. Pada layananan jasa, produksi dan konsumen dilakukan secara simultan, dimana penyedia jasa dan konsumen berbeda pada saat yang sama ketika proses pemberian jasa berlangsung. Sedabgkan pada produksi barang terdapat perbedaan waktu. Hal tersebut menggakibatkan barang disimpan, sedangkan jasa tidak dapat disimpan. Implikasinya,interaksi antara pemberi jasa dengan konsumen akan sangat menentukan proses yang terjadi.

Demikian pula dalam menerapkan sistem kualitas, tidak semua yang diterapkan dalam produksi barang dapat diterpakan dalam layanan jasa pada produksi barang, kualitas dapat didefinisikan sebagai kesesuaian dengan persyaratan produk, sedangkan dalam jasa kualitas dinilai dari sudut pandang konsumen. Perubahan lingkungan berpengaruh pada jasa dan kualitas pelayanannya. Banyaknya jasa atau layanan yang sama yang ditawarkan oleh berbagai pihak akan menyebabkan konsumen mempunyai banyak pilihan. Pelayanan jasa tidak dimaksudkan untuk menghasilkan suatu produk, tetapi untuk memenuhi apa yang terjadi keinginan dan harapan konsumen.

Apabila aspek contact personal dilupak maka perusahaan akan kehilangan

Pelanggannya . oleh karena itu peranan aspek tersebut penting untuk menentukan kualitas jasa, sehingga setiap perusahaan memerlukan service excellence. 
Yaitu pelayanan sangat unggul yang diberikan oleh suatu perusahaan kepada para pelanggan dengan sikap atau cara karyawan dalam melayani pelanggan secara memuaskan.

Perusahaan yang dapat memberikan pelayanan berkulitas secara konsisten sesuai dengan harapan pelanggan, dapat menumbuhkan kepuasan pelanggan. Kualitas yang unggul dapat digunakan sebagai alat untuk meraih keunggulan bersaing dalam berbagai organisasi atau perusahaan.

\section{Dimensi Kualitas Pelayanan}

Ada sejumlah dimensi yang dapat digunakan untuk menganalisis sejauh mana pelayanan jasa telah memenuhi harapan konsumen. Menurut Tjiptono (2008) Ada empat karakteristik jasa/layanan yang membedakannya dari barang yaitu ada lima dimensi yang dapat dijadikan kriteria untuk mengetahui kesenjangan antara persepsi dan harapan konsumen, diantaranya sebagai berikut :

1. Keberwujudan (Tangible quality) yang terdiri dari bukti fisik pelayanan yang terwujud dalam :

a. Bentuk fasilitas fisik ( apakah menarik atau tidak )

b. Jumlah karyawan (apakah memadai atau tidak )

c. Peralatan dan sarana (kehandalan atau kelengkapanya)

d. Material komunikasi (apakah dapat dimengerti atau tidak

2. Empati (Emphaty)

Sikap dari petugas dengan memberikan perhatian pribadi bagi para pelangan yang ditunjukan dengan kemudahan untuk berkomunikasi tentang pelayanan jasa yang akan diberikan.

3. Kehandalan (reliability), yang terdiri dari :

a. Kemampuan pelayan untuk menghasilkan kinerja yang sudah dijanjikan dengan segera.

b. Keakuratan dan kepastian yang ditetapkan dalam bentuk kecermatan dan disiplin.

4. Kesingapan (Responsiveness)

Tanggapnya untuk memberikan pelayanan terhadap kebutuhan pelanggan yang ditunjukan dalam kesiapan untuk memberikan bantuan dan memberikan pelayanan yang terbaik.

5. Keterpercayaan ( Assurance of Integrity)

a. Kemampuan pelayanan untuk menyediakan jaminan tersediannya pelayanan tepat pada waktunya dan sesuai dengan apa yang menjadi kepentingan konsumen yang ditunjukan oleh ketulusan.

b. Kompetensi ( dimilikinya pengetahuan dan kemampuan yang dikaitkan dengan pelaksanaan tugas ).

c. Dapat dipercaya d. Memberikan rasa aman atau bebas dari resiko.

Kulitas pelayanan didefinisikan sebagai penyapayain jasa yang akan melebihi tingkat kepentinggan pelanggan Rangkuti, (2002) jenis kualitas yang digunakan untuk menilai kualitas pelayanan adalah sebagai berikut :

1. Kualitas teknik ( outcome), yaitu kualitas hasil kerja penyapaian jasa itu sendiri.

2. Kualitas pelayanan ( proses / fungsional), yaitu kualitas cara penyapaian jasa tersebut.

Kedua kualitas pelayanan tersebut menentukan citra corporate (perusahaan) yang pada gilirannya dapat mempegaruhi kualitas pelayanan yang dipersepsikan pelanggan

Berdasarkan uraian diatas, maka penulis dapat menyimpulkan bahwa untuk mengukur kualitas pelayanan yaitu dengan dimensi tangible, emphaty, reliability, responsiveness, and assurance.

Untuk memahami pengertian kepuasan pelanggan, perlu dicermati beberapa hal yang berkaitan dengan tercapainya kepuasan pelanggan. Menurut Lupiyoadi, dkk (2008) ada beberapa aspek dalam mengetahui kepuasan pelanggan yakni:

1. Memperkecil terjadinya kesenjangankesenjangan yang terjadi antara pihak manajemen dan pelanggan

2. Perusahaan harus mampu untuk membangun komitmen bersama untuk menciptakan visi didalam perbaikan proses pelayanan

3. Memberi kesempatan kepada pelanggan untuk menyampaikan keluhan

4. Mengembangkan dan menerapkan accountable, proactive, dan partnership marketing sesuai dengan situasi pemasaran

Menurut pendapat Kotler (2006) "Customer satisfaction is a person's feeling of pleasure or disappointment resulting from comparing a products perceived performance in relation to his or her expectarions". Kepuasan pelanggan merupakan perasaan senang/kecewa yang dirasakan pelanggan setelah membandingkan antara sesuatu yang diterima/diperoleh dengan yang diharapkan oleh pelanggan tersebut dimana kalau kenyataan yang diterima sesuai dengan harapan maka pelanggan tersebut akan puas dan apabila kenyataan yang diterima tidak sesuai dengan harapannya, maka pelanggan tersebut tidak akan puas.

Philip Kotler, mengungkapkan (2000) bahwa: Kepuasan merupakan tingkat perasaan dimana seseorang menyatakan hasil perbandinan antara hasil 
kerja produk / jasa yang diterima dengan apa yang diharapkan.

Ada kesamaan diatara beberapa definisi diatas yaitu menyakut komponen kepuasan konsumen (harapan kinerja/ hasil yang dirasakan). Umumnya harapan konsumen merupakan perkiraan atau keyakinan konsumen tentang apa yang akan diterimanya apabila ia membeli atau mengkonsumsi, suatu produk baik itu berupa barang atau jasa. Sehingga sebelum konsumen membeli suatu produk ia sudah mempunyai harapan atau kualitas produk yang akan didapat. Sedangkan kinerja yang dirasakan oleh konsumen adalah prespsi konsumen terhadap apa yang diterima setelah mengkonsumsi produk yang dibeli.

Pada umumnya program kepuasan pelanggan mencakup kembinasi dari tujuah elemen utama Tjiptono (2004) yakni:

1. Barang dan jasa berkualitas

Pada umumnya Perusahaan menerapkan konsep kepuasan pelanggan harus memiliki produk berkualitas baik dan layanan yang prima. Setidaknya standarnya harus menyamai pesaing utama dalam industri. Maka dari itu, berlaku prinsip "quality comes first, satisfaction programs follow". Yang biasanya perusahaan yang tingkat kepuasan pelanggannya tinggi menyediakan tingkat layanan pelanggan yang tinggi pula. Sering kali ini merupakan cara menjustifikasi harga yang lebih mahal.

2. Relationship marketing

Kunci utama dalam setiap program promosi loyalitas adalah upaya menjalin relasi jangka panjang dengan para pelanggan. Asumsinya adalah bahwa relasi yang kokoh dan saling menguntungkan antara penyedia jasa dan pelanggan dapat membangun bisnis ulangan (repeat business) dan menciptakan loyalitas pelanggan.

3. Program promosi

Program ini banyak diterapkan oleh perusahaan dan pelanggan. Program yang dilakukan memberikan semacam penghargaan (rewards) khusus, seperti bonus, diskon, voucher, dan hadiah yang dikaitkan dengan frekuensi pembelian atau pemakaian produk/jasa perusahaan kepada pelanggan rutin (heavy users) agar tetap loyal pada produk dari perusahaan bersangkutan. Melalui program kerjasama seperti itu diharapkan kemampuan menciptakan dan mempertahankan kepuasan serta loyalitas pelanggan akan semakin besar.

4. Fokus pada konsumen terbaik (best customers) Pelanggan yang baik tidak hanya sekedar mereka yang termasuk heavy users atau pelanggan yang berbelanja dalam jumlah banyak. Tetapi, criteria lainnya yang menyangkut pembayaran yang lancar dan tepat waktu, tidak terlalu banyak membutuhkan layanan tambahan (karena mereka telah sangat paham mengenai cara berinteraksi dengan perusahaan), dan relatif tidak sensitif dan tidak perduli terhadap harga (lebih menyukai stabilitas daripada terus-menerus berganti pemasok untuk mendapatkan harga termurah) juga termasuk dalam kategori pelanggan terbaik.

5. Sistem penanganan komplain secara efektif Penanganan complain terkait erat dengan kualitas produk. Perusahaan harus memperhatikan dan memastikan bahwa barang dan jasa yang dihasilkan benar-benar berfungsi sebagaimana mestinya sejak awal. Ketika jika terjadi masalah, perusahaan segera berusaha memperbaikinya lewat system penanganan complain. Jadi jaminan kualitas harus mendahului penanganan complain. Sistem yang khusus penanganan komplain yang efektif membutuhkan beberapa aspek, seperti (1) permohonan maaf kepada pelanggan atas ketidaknyamanan yang mereka alami; (2) empati terhadap pelanggan yang marah; (3) kecepatan dalam mengatasi keluhan; (4) kewajaran yang terjadi atau keadilan keadilan dalam memecahkan masalah/keluhan; dan (5) kemudahan bagi pelanggan untuk menghubungi perusahaan (via telepon saluran bebas pulsa, surat, e-mail, fax, maupun tatap muka langsung) dalam upaya menyampaikan komentar, kritik, saran, pertanyaan dan komplain. Keterlibat langsung seorang manajemen puncak dalam mengatasi pelanggan juga sangat penting, karena bias mengkomunikasikan secara nyata komitmen perusahaan dalam memuaskan setiap pelanggan. Selain itu, para staf layanan pelanggan harus diseleksi dan dipantau secara cermat guna memastikan bahwa mereka benar-benar berorientasi pada pemuasan kebutuhan pelanggan.

6. Unconditional guarantees

Garansi yang adalah janji eksplisit yang disampaikan kepada para konsumen mengenai tingkat kinerja yang dapat diharapkan akan mereka terima. Garansi yang diberikan ini bermanfaat dalam mengurangi risiko pembelian oleh pelanggan, memberikan sinyal mengenai kualitas produk, dan secara tegas menyatakan bahwa perusahaan bertanggung jawab atas produk atau jasa yang diberikannya. Garansi yang diberikan harus baik dan memiliki beberapa karakteristik pokok, seperti (1) tidak bersyarat (tidak dibebani dengan berbagai macam peraturan, ketentuan, atau pengecualian yang membatasi ataupun menghambat kebijakan 
pengembalian atau kompensasi); (2) spesifik; (3) realistis, yakni tidak bombastis yang cenderung tidak bisa dipenuhi; (4) berarti/ meaningful (mencakup aspek-aspek penyampaian jasa yang penting bagi pelanggan); (5) dinyatakan dalam bahasa yang sederhana dan mudah dimengerti dan dipahami (tidak dalam bahasa hukum yang berbelit-belit); dan (6) mudah direalisasikan atau ditagih bila menyangkut kompensasi atau ganti rugi tertentu.

7. Program pay-for-performance

Program kepuasan konsumen atau pelanggan tidak bisa terlaksana tanpa adanya dukungan sumber daya manusia organisasi. Sebagai upaya atau ujung tombak perusahaan yang berinteraksi langsung dengan para pelanggan dan berkewajiban memuaskan mereka, karyawan juga harus dipuaskan kebutuhannya. Dengan maksud lain, total customer satisfaction harus didukung pula dengan total quality reward yang mengaitkan sistem penilaian kinerja dan kompensasi dengan kontribusi setiap karyawan dalam penyempurnaan kualitas dan peningkatan kepuasan pelanggan.

Kepuasan konsumen menyatakan bahwa kepuasan dari ketidak puasan adalah respon konsumen terhadap evaluasi kesesuaian (disconfirmation) yang dirasakan antara harapan sebelumnya dengan kinerja aktual produk yang dirasakan setelah pemakaiannya.

Variable utama yang menentukan kepuasan konsumen, yaitu expectations (apa yang diharapkan) dan perceived ferformance (pelayanan yang diterima). Apabila performance melebihi expectations maka pelanggan akan merasa puas, tetapi apabila sebaliknya yaitu perceived performance jauh dibawah expectations maka pelanggan akan merasa tidak puas. Seorang pelanggan yang puas adalah pelanggan yang merasa mendapatkan value (nilai) dari produsen atau penyedia jasa. Nilai ini bisa berasal dari produk, pelayanan, system atau suatu yang bersifat emosi. Jika pelanggan mengatakan bahwa nilai adalah produk yang berkualitas, maka kepuasan akan terjadi kalau pelanggan mendapatkan produk yang berkualitas.

Nilai bagi pelanggan ini dapat diciptakan melalui atribut - atribut pemasaran perusahaan yang dapat menjadi unsur-unsur stimuli bagi lembaga untuk mempengaruhi konsumen dalam pembelian. Jika pembelian yang dilakukan mampu memenuhi kebutuhan dan keingginanya atau mampu memberikan kepuasan, maka di masa datang akan terjadi pembelian ulang. Bahkan lebih jauh lagi, konsumen yang puas akan menyampaikan rasa kepuasannya kepada orang lain, baik dalam cerita (word of mouth), atau memberikan rekomendasi.

Efek berantai yang dihasilakn dari mekanisme ini akan jauh lebih efektif dibandingkan dengan iklan dimedia massa. Karenanya lembaga pendidikan harus mampu memberikan pelayanan yang terbaik sesuai dengan janjinya agar mampu menghasilkan efek word of mouth yang positif bagi lembaga pendidikan. Oleh karna ini banyak iklan yang menyajikan tampilan dengan unsure testimony atau kesaksian atas suatu produk tertentu. Dihapkan dengan tampilan iklan yang berisi kesaksian mampu mempengaruhi pihak lain untuk membeli, merasakn produk dan jasa tersebut.

Disamping itu juga, dalam menentukan tingkat kepuasan pelanggan Menurut Lupiyoadi (2001), terdapat lima faktor utama yang harus diperhatikan oleh perusahaan dalam menentukan tingkat kepuasan pelanggan, yaitu :

1. Kualitas produk Pelanggan akan merasa puas bila hasil evaluasi mereka menunjukan bahwa produk yang mereka gunakan berkualitas, konsumen rasional selalu menuntut produk yang berkualitas untuk setiap pengorbanan yang dilakukan untuk memperoleh produk tersebut. Dalam hal ini kualitas produk yang baik akan memberikan nilai tambah dibenak konsumen.

2. Kualitas pelayanan terutama dibidang jasa, pelanggan akan merasa puas bila mereka mendapatkan pelayanan yang baik atau yang sesuai dengan yang diharapkan. Pelanggan yang puas akan menujukkan kemukinan untuk kembali membeli produk yang sama. Pelanggan yang puas cenderung akan memberikan persepsi terhadap produk perusahaan.

3. EmosionalPelanggan akan merasa bangga dan mendapatkan keyakinan bahwa orang lain akan kagum terhadap dia bial mengunakan produk dengan merek tertentu yang cenderung mempunyai tingka kepuasan yang lebih tinggi. Kepuasan yang diperoleh. Bukan karena kualitas dari produk tetapi nilai sosial atau self esteem yang membuat pelanggan menjadi puas terhadap merk tertentu.

4. HargaProduk yang mempunyai kualitas yang sama tetapi menentapkan harga yang relatif murah akan memberikan nilai yang lebih tinggi kepada pelanggannya.

5. Biaya Pelanggan tidak perlu mengeluarkan biaya tambahan atau tidak perlu membuang waktu untuk mendapatkan suatu produk atau jasa cenderung puas terhadap produk atau jasa itu. 
Pada prinsipnya perlu dilakukan berbagai strategi kepuasan pelanggan yang akan menyebapkan setiap pedagang jasa untuk bekerja keras dalam usahanya memperebutkan pelanggan dan memenuhi bebagai harapan yang diinginkan pelanggan terhadap jasa. Harapan pelanggan dibentuk dan dirasakan oleh beberapa faktor, diantaranya pengalaman berbelanja damasa lampau, opini teman dan kerabat, serta informasi dan janji-janji perusahaan dan para pesaing.

Faktor-faktor tersebutlah yang menyebapkan persepsi yang berbeda-beda dari pelanggan terhadap kualitas suatu jasa. Dengan demikian, setiap pedagang jasa harus benar-benar memperhatikan kualitas jasa yang mereka miliki, agar setiap pelanggan, sebagai penguna jasa dapat memperoleh kepuasan yang maksimal dari jasa yang disediakan. Definisi kualitas jasa itu sendiri berpusat pada upaya pemenuhan kebutuhan dan keinginan pelanggan serta ketepatan penyampaian untuk mengimbangi harapan pelanggan. Menurut Wycof dalam Fandy Tjiptono, (2007) bahwa "kualitas jasa adalah tingkat keunggulan yang diharapkan dan pengendalian atas tingkat keunggulan tersebut serta memenuhi keinginan pelanggan".

Kegiatan yang dilakukan perusahaan, pada akhirnya akan bermuara pada nilai yang akan diberikan oleh pelanggan mengenai kepuasan yang dirasakan. Karena pada dasarnya pelanggan sebagai penguna jasa akan secara otomatis menilai tentang keseluruhan kualitas jasa yang telah diberikan perusahaan sebagai penyedia jasa kepada para pelanggan.

Berdasarkan uraiyan diatas, maka tujuan permasalahan ini adalah untuk menganalisis faktorfaktor bukti fisik (tangibles), kehandalan (reliability), daya tanggap (responsiveness), jaminan (assurance), empati (empathy). Sejauh mana berpengaruh terhadap kepuasan pelanggan Taam Aisyah Kota Bandung.

\section{Metodologi Penelitian}

Metode yang digunakan dalam permasalahan ini adalah metode deskriptif dan metode asosiatif. Metode deskriptif yaitu metode penelitian yang dilakukan untuk mengetahui dan menjelaskan karakteristik variabel-variabel dari situasi atau keadaan Bambang S. Soedibjo (2005). Sedangkan metode asosiatif atau disebut juga metode korelasional digunakan untuk melihat hubungan atau pengaruh antara dua atau lebih variabel. Penelitian asosiatif kelanjutan dari metode deskriptif dimana kita hanya menghimpun, menyajikan data secara cermat dan teliti Bambang S. Soedibjo (2005). Jenis data yang dipergunakan dalam penelitian ini adalah data primer. Data primer adalah informasi yang diperoleh pertama kali peneliti menyangkut variabel yang menjadi tujuan utama penelitian Bambang S. Soedibjo (2005). Sumber data ini pererongan.

Sumber data yang digunakan adalah data primer dan data sekunder, yaitu dengan melakukan observasi serta menyebarkan kuesioner kepada responden. Teknik pengambilan sampel dalam penelitian ini adalah lembar angket teknik sensus. Ukuran sampel dalam penelitian ini sebanyak 33 responden. Untuk melihat derajat hubungan antara variabel dependent dengan variabel independent digunakan criteria champion Bambang S.Soedibjo (2005) berikut ini : Untuk melihat derajat hubungan antara variabel dependent dengan variabel independent digunakan criteria champion Bambang S.Soedibjo (2005) berikut ini :

Tabel 2 Klasifikasi Koefisien Korelasi

\begin{tabular}{|c|l|}
\hline $\begin{array}{c}\text { Interval } \\
\text { Koefisien }\end{array}$ & \multicolumn{1}{|c|}{ Tingkat Hubungan } \\
\hline$+/-0,00-$ & Tidak ada hubungan atau hubungan \\
0,25 & yang sangat lemah \\
\hline$+/-0,26-$ & Hubungan yang cukup kuat \\
0,50 & \\
\hline$+/-0,51-$ & Hubungan yang kuat \\
0,75 & \\
\hline$+/-0,76-$ & Hubungan sangat kuat \\
1,00 & \\
\hline
\end{tabular}

Sumber : Bambang S. Soedibjo (2005)

Dalam permasalahan ini digunakan dua variabel yaitu : Kualitas Pelayanan (X) yang merupakan variabel bebas (independent), dan Kepuasan (Y) sebagai variabel terikat (dependent)

HASIL DAN PEMBAHASAN

Pengaruh Kualitas Pelayanan Terhadap Kepuasan Pelanggan Pada Taam Aisyah

Terdapat Pengaruh Kualitas Pelayanan Terhadap Kepuasan Pelanggan Pada Taam Aisyah, maka pengujian untuk mengetahui hubungan antara variabel $\mathrm{X}$ dan $\mathrm{Y}$ dicari dengan mungunakan rumus korelasi rank Spearman.

Tabel 3 Persentase Tingkat Pencapaian Variabel Kualitas Pelayanan

\begin{tabular}{|l|l|c|}
\hline No & \multicolumn{1}{|c|}{ Dimensi } & $\begin{array}{c}\text { Tingkat } \\
\text { Pencapaian }\end{array}$ \\
\hline 1 & Bukti Langsung (Tangible) & 135,3 \\
\hline 2 & Kehandalan (Reliability) & 139,3 \\
\hline 3 & $\begin{array}{l}\text { Daya tanggap } \\
\text { (Responsiveness) }\end{array}$ & 133,3 \\
\hline 4 & Jaminan (Assurance) & 150,3 \\
\hline 5 & Perhatian (Emphaty) & 151 \\
\hline & Rata-rata & 141,84 \\
\hline
\end{tabular}




\section{Sumber : Hasil pengolah data}

Dari tabel diatas terlihat rata-rata tingkat pencapaian persetujuan responden untuk variabel Kualitas Pelayanan (Variabel X) mencapai 141,84 hasil ini mencerminkan bahwa kondisi "Kualitas Pelayanan Dalam Kondisi Sangat Baik".

Tabel 4 Persentase Tingkat Pencapaian Variabel Kepuasan pelanggan

\begin{tabular}{|l|l|c|}
\hline No & \multicolumn{1}{|c|}{ Dimensi } & $\begin{array}{c}\text { Tingkat } \\
\text { Pencapaian }\end{array}$ \\
\hline 1 & Kualitas Produk & 147 \\
\hline 2 & Kualitas Pelayanan & 145 \\
\hline 3 & Emosional & 145 \\
\hline 4 & Harga & 147,6 \\
\hline 5 & Biaya & 144,3 \\
\hline & Rata Rata & 145,78 \\
\hline
\end{tabular}

Sumber : Hasil pengolah data

Dari tabel diatas terlihat rata-rata tingkat pencapaian persetujuan responden untuk variabel Kepuasan pelanggan ( Variabel Y ) mencapai 145,78, hasil ini mencerminkan bahwa kondisi " Kepuasan pelanggan dalam kondisi sangat baik".

Dengan mengunakan program computer SPSS ver. 18 , maka diperoleh koefisien korelasi atau Rho Spearman di dapat nilai $\rho=(+) 0,728$ (hasil penghitungan dapat dilihat pada lampiran) dari hasil penghitungan SPSS tersebut positif artinya jika kualitas pelayanan baik maka akan meningkatkan kepuasan (hasil perhitungan dapat di lihat pada lampiran). Berdasarkan kriteria Champion hubungan yang kuat. Dengan demikian dapat dikatakan bahwa perubahan positif yang terjadi pada kepuasan pelanggan cukup kuat ditentukan oleh faktor kualitas pelayanan pada Taam Aisyah Bandung.

Sedangkan untuk mengetahui besarnya pengaruh kualitas pelayanan terhadap kepuasan pelanggan adalah sebesar :

$$
\begin{aligned}
\mathrm{KD} & =\rho^{2} \times 100 \% \\
\mathrm{KD} & =(0,728)^{2} \times 100 \% \\
& =52,99 \%
\end{aligned}
$$

Artinya kualitas pelayanan hanya mampu berpengaruh sebesar 52,99 \% terhadap kepuasan pelanggan pada Taam Aisyah Bandung. Sisanya dipengaruhi oleh faktor-faktor lain yang tidak di teliti oleh penulis.

\section{KESIMPULAN}

Berdasarkan hasil penelitian dan pembahasan yang telah diuraikan pada bab sebelumnya, maka dapat ditarik kesimpulan Kualitas Pelayanan Pada Taam Aisyah berdasarkan analisis deskriptif atas frekuensi jawaban 33 responden menujukkan tingkat pencapaian kualitas pelayanan rata-rata sebesar 141,84 ini menunjukkan bahwa kualitas pelayanan sangat baik; Kepuasan Pada Taam berdasarkan analisis deskriptif atas frekuesi jawaban 33 responden menunjukkan tingkat kepuasan rata-rata sebesar 145,78 ini menunjukkan bahwa tingkat kepuasan sangat baik. Berdasarkan koefisien korelasi rank Spearman sebesar (+) 0,728 dan masuk dalam katagori hubungan yang kuat menurut kriteria Champion. Arah koefisien yang positif menunjukan pula bahwa semakin baik kualitas pelayanan maka akan diikuti dengan semakin tinggi kepuasan pelanggan. Besarnya pengaruh kualitas pelayanan terhadap kepuasan pelanggan sebesar 52,99 \% sedangkan sisanya di tentukan oleh faktor lain yang tidak diteliti oleh penulis.

\section{REFERENSI}

Assauri, Sofjan. Manajemen Pemasaran: Dasar, Konsep, dan Strategi." (2013).

Bambang S. Soedibjo ,(2005) Pengatar Metode Penelitian untuk Jurusan Manajemen STIE PASIM.

Fandy. Tjiptono,(2001) Manajemen Jasa, Andi Offset, Jogjakarta

Gasper SZ, V . ( 2005 ) Total Quality Management, Jakarta : PT . Gramedia Pustaka Utama.

Kotler dan Keller. 2009. Manajemen Pemasaran Jilid 1. Edisi ke 13 Jakarta; Erlangga

Kotler dan Armstrong 2012 . Prinsip Prinsip Pemasaran 2. Edisi ke 13 Jakarta; Erlangga

Kumar, M., Kee, F.T., \& Manshor, A.T. (2009). Determining the Relative Importance of Critical Factors in Delivering Service Quality of Banks: An Application of Dominance Analysis in SERVQUAL Model, 
Lovelock, C.H \&Wright, L.K. (2007).Manajemen Pemasaran Jasa. (Edisi Bahasa Indonesia). Jakarta: PT Indeks.

Lupiyoadi, Rambat. (2001), Manajement Pemasaran Jasa Teori dan Praktik Jakarta : Penerbit Salemba Empat.

Lupiyoadi, Dkk. (2008), Manajement Pemasaran Jasa Teori dan Praktik Jakarta : Penerbit Salemba Empat.

Prasetyo, W.B. (2013). Pengaruh Kualitas Pelayanan, Kepercayaan Dan Kepuasan Terhadap Kesetiaan Pelanggan: Studi pada Swalayan Luwes Purwodadi. Diakses dari http://eprints.dinus.ac.id/ 5069/1/12708.pdf pada tanggal 30 Maret 2016.

Rangkuti, Freddy. (2002). Measuring Customer Satisfaction (cetakan ketiga). Jakarta : Pt Gramedia Pustaka Utama.
Sugianto, T. (2009), Pengaruh Pemberian Kredit Umum Pedesaan Sebagai kredit Mikro Terhadap Pencapaian Laba di PT. Bank Rakyat Indonesia (Persero), Tbk Kantor Cabang Majalaya Unit Nagreg, Bandung : Skrpsi pada STIE Kridatama, tidak diterbitkan.

Tjiptono, Fandy (2007). Strategi Pemasaran. Edisi Pertama. Andi Ofset. Yogyakarta.

Untari, D. (2018). Peranan Administrasi Pemasaran Produk Sari Husada PT Tigaraksa Satria Tbk Cabang Bandung. Jurnal Cano Ekonomos, 7(2), 26-40. 